\title{
Spotkanie po ASCO 2014
}

Trzynaste "Spotkanie po ASCO” za nami, odbyło się w dniach 27-28 czerwca 2014 r. w Gdańsku. Tradycyjnie podsumowano na nim najważniejsze doniesienia Kongresu Amerykańskiego Towarzystwa Onkologii Klinicznej (ASCO), który odbył się niespełna miesiąc wcześniej w Chicago. Tegoroczny kongres był wyjątkowy, bowiem ASCO świętuje swoje 50-lecie. Najważniejszym tematem jubileuszowego spotkania, który przewijał się niemal we wszystkich sesjach tematycznych, była otyłość, określona jako plaga XXI wieku, przypominająca plagę XX wieku, czyli palenie tytoniu. W krajach bogatych palenie tytoniu zanika, natomiast otyłość systematycznie rośnie, najbardziej w grupie dzieci i młodzieży. Temat otyłości był także obecny w wykładach podczas „Spotkania po ASCO”. Wzorem ubiegłych lat uczestnicy "Spotkania..." otrzymali w materiałach zjazdowych broszurę „Polacy na ASCO”, która przedstawia prace zaprezentowane przez polskich autorów na tegorocznym, 50. Kongresie ASCO.

\section{Biologia nowotworów i nowe leki}

Piotr Wysocki

Bardzo intensywnie badane są nowe leki związane ze szlakami przekazu sygnału z receptora MET, Wnt czy Hh (Hedgehog). Nowym celem terapeutycznym staje się także autofagia - mechanizm wrodzonej odporności, uruchamiany przez komórkę w różnych sytuacjach stresowych (np. niedobór substratów czy zakażenie). Autofagia pozwala eliminować z komórki wirusy, bakterie, ale również degradować niektóre organella wewnątrzkomórkowe, które mogłyby w sytuacji stresu ulegać uszkodzeniom i uczestniczyć w procesie karcynogenezy. Jest to zatem mechanizm korzystny, chroniący komórkę przed wytworzeniem fenotypu nowotworowego. Z drugiej strony jednak mechanizm autofagii w zaawansowanym procesie nowotworowym chroni komórkę przed skutkami takich czynników stresowych jak leki przeciwnowotworowe czy radioterapia. Proces autofagii jest regulowany przez szereg czynników, m.in. przez szlaki sygnałowe kinaz. Stosowanie różnych substancji modulujących może pobudzać proces autofagii w komórkach z defektem, zagrożonych przemianą nowotworową, oraz hamować proces autofagii w komórkach nowotworowych w trakcie leczenia (abstr. TPS2640; badanie I fazy oceniające wartość substancji hamujących autofagię w zaawansowanych guzach litych). Pojawiają się również prace wykazujące, że zaburzenia funkcji genów kodujących białka regulujące proces autofagii mogą mieć znaczenie prognostyczne (abstr. E14506).

Szlak sygnałowy Notch jest odpowiedzialny za regulacje procesów związanych z nabywaniem określonego fenotypu podczas różnicowania komórek oraz regulację przeżywalności i międzykomórkowych interakcji. W zaawansowanych nowotworach aktywacja szlaku Notch odpowiada za progresję procesu nowotworowego. Demicyzumab to przeciwciało monoklonalne lgG2 dla liganda receptora Notch. Jego zastosowanie hamuje wzrost guza, zmniejsza populację macierzystych komórek nowotworowych oraz zaburza proces neoangiogenezy. W badaniu I fazy skojarzenie demicyzumabu z karboplatyną i pemetreksedem u chorych na niepłaskonabłonkowego raka płuca związane było z nadciśnieniem płucnym i niewydolnością mięśnia sercowego (abstr. 2544).

Macierzyste komórki nowotworowe stanowiące punkt wyjścia nowotworu są komórkami wolno proliferującymi, samoodnawialnymi i posiadają wykształcone mechanizmy oporności wielolekowej, co powoduje, że pomimo leczenia nie ulegają zniszczeniu i stanowiąźródło odnowy guza. Teoria komórek macierzystych znana jest od dawna, jednak dopiero w ostatnich latach poznaliśmy charakterystyczne cechy oraz mechanizmy pobudzania wzrostu tych komórek, co pozwala wprowadzać do badań skierowane przeciwko nim leki.Trwają liczne badania (głównie wczesnych faz) z zastosowaniem preparatów zmniejszających populację macierzystych komórek nowotworowych, co hamuje wzrost guza oraz pobudza różnicowanie komórek nowotworowych (abstr. 2505, 2530, 2545).

Krążące komórki nowotworowe to populacja komórek uwolnionych z guza, obecnych w krwiobiegu i stanowiących źródło przerzutów odległych. Ich znaczenie prognostyczne potwierdzono jak dotąd w raku piersi (mataanaliza z 2014, Lancet Oncology). Obecnie można izolować te komórki i oznaczać ich fenotyp, co pozwala określić ich rolę w innych nowotworach (abstr. 11041), oceniać biologię guza w przypadku nawrotu (abstr. 7563, 11017), czy wreszcie przewidywać odpowiedź na leczenie (abstr. 5001). 


\section{Epidemiologia i profilaktyka}

Renata Duchnowska

Nadwaga i otyłość jest zmorą naszych czasów, a problem ten nasila się przede wszystkim wśród dzieci i młodzieży. W krajach rozwiniętych co dziesiąta osoba w wieku poniżej 18 lat cierpi na nadwagę lub otyłość. W odniesieniu do wielu nowotworów otyłość jest czynnikiem ryzyka, a wyniki leczenia są zdecydowanie gorsze u chorych otyłych. Te znane od lat obserwacje kliniczne są obecnie potwierdzone badaniami zależności pomiędzy otyłością, wytwarzaniem hormonów i mediatorów stanu zapalnego (ścieżka CHIEF - Convergence of Hormones, Inflammation and Energy-related Factors Pathway). W prospektywnym badaniu z losowym doborem chorych przeprowadzonym w grupie chorych na raka piersi otyłych i po menopauzie wykazano, że umiarkowane, ale regularne ćwiczenia fizyczne prowadzące do zmniejszenia masy ciała wpłynęły korzystnie na stężenie hormonów płciowych - estrogenów $(p \leq 0,05)$, testosteronu $(p=0,01)$ oraz białka wiążącego hormony płciowe ( $p<0,0001$ ) związanych z ryzykiem zachorowania na raka piersi (abstr. 1504, badanie SHAPE-2). Dieta niepołączona z wysiłkiem pozwoliła na obniżenie masy ciała, jednak pozostało to bez wpływu na stężenie hormonów płciowych, co wskazuje na istotną rolę aktywności fizycznej. U chorych na raka piersi wykazano, że zmniejszenie masy ciała obniża poziom mediatorów stanu zapalnego (leptyny, IL-6) i parametrów metabolicznych (insuliny, glikemii), natomiast otyłość i stan po menopauzie zwiększają intensywność prokancerogennych procesów zapalnych w tkance tłuszczowej (abstr. 1505 i 512). Podczas kongresu ASCO wielokrotnie powtarzano, że dieta i aktywność fizyczna mają największe znaczenie w walce $z$ otyłością, leczenie farmakologiczne i chirurgiczne pełnią znacznie mniejszą rolę.

Profilaktyczna obustronna resekcja przydatków u chorych na wczesnego raka piersi będących nosicielkami mutacji BRCA1/2 pozwala obniżyć umieralność w grupie kobiet z mutacją BRCA1 (HR 0,59 [95\% Cl: 0,34-1,01]; $\mathrm{p}=0,05$ ) oraz chorych na raka piersi bez ekspresji receptora estrogenowego (HR 0,27 [95\% Cl: 0,11-0,67]; $p=0,005)$. U takich kobiet powinno się rozważyć profilaktyczne usunięcie przydatków tuż po zakończeniu radykalnego leczenia z powodu wczesnego raka piersi.

Nadchodzi era komercyjnego stosowania wielogenowych testów, szczególnie dla genów najwyższej (BRCA1/2, TP53, PTEN) lub umiarkowanej (BRIP1, CHEK2, PALB2) penetracji. Trwają badania mające na celu doprecyzowanie kryteriów doboru osób do wykonania tych testów (abstr. $1509,1510,1511)$. Nie należy zapominać, że testy wielogenowe dostarczają wielu informacji, również o ryzyku rzadko występujących uszkodzeń, ale nie zawsze można te informacje wykorzystać w praktyce i wdrożyć skuteczne działania prewencyjne lub lecznicze.

\section{Chłoniaki}

Renata Zaucha

Ostatnie lata przynoszą znaczny postęp w zakresie diagnostyki obrazowej (wykorzystanie PET/CT do oceny zaawansowania czy monitorowania odpowiedzi) oraz molekularnej (typowanie o znaczeniu prognostycznym, ocena efektów leczenia zależnie od podtypu) chłoniaków. Ciekawą koncepcją wydaje się być oznaczanie krążącego DNA nowotworu w osoczu (MRD - molecular residual disease) dla rozpoznawania progresji (abstr. 8504). Metoda ma niezbyt wysoką czułość, ale charakteryzuje się 100\% swoistością i nie naraża chorego na promieniowanie jonizujące, jak to ma miejsce w przypadku badania PET/CT.

Standard leczenia rozlanych chłoniaków z dużej komórki (DLBCL) - chemioterapia CHOP w skojarzeniu z rituksymabem - pozostaje niezmienny od lat. Niestety, 5 lat przeżywa zaledwie połowa chorych, a większość nawrotów pojawia się w ciągu 1,5 roku. Stąd nieustanne próby intensyfikacji leczenia poprzez zwiększenie liczby cykli, stosowanie wlewów ciągłych, bardziej intensywną indukcję czy stosowanie leczenia podtrzymującego. Poszukiwano również dobrych sposobów stratyfikacji chorych poprzez różne modyfikacje wskaźnika IPI, czy też stosowanie wczesnej oceny w badaniu $\mathrm{PET} / \mathrm{CT}$. Obecne badania mają na celu identyfikację podtypów molekularnych i ocenę wartości leczenia w tych podtypach.W DLBCL wyróżnia się kilka podtypów, m.in.z profilem ekspresji genów komórek B ośrodków rozmnażania (GCB, germinal center $B$-cell-like) oraz komórek $B$ niepochodzących z ośrodków rozmnażania (non-GCB), przy czym wyniki leczenia podtypu non-GCB są znacznie gorsze. Dołączenie lenalidomidu do schematu RCHOP poprawiło wyniki leczenia (ORR, PFS, OS), przy czym szczególną korzyść obserwowano w grupie chorych na chłoniaka non-GCB (abstr. 8520).

Chłoniaki z komórek płaszcza występują rzadko (6\% wszystkich chłoniaków), ale charakteryzują się szczególnie złym rokowaniem, u większości chorych progresja występuje przed upływem 2 lat. Wyniki leczenia R-CHOP są niezadowalające. Wprawdzie u ok. 20\% chorych obserwuje się powolny przebieg, co pozwalałoby nie podejmować leczenia w chwili rozpoznania, jednak tę grupę chorych trudno zidentyfikować. Leczenie postaci nawrotowych i opornych jest niezwykle trudne, a dotychczasowe próby zastosowania bortezomibu, temsyrolimusu czy lenalidomidu nie przyniosły efektu. W badaniu III fazy z losowym doborem chorych oceniono skuteczność i tolerancję leczenia 1. linii schematem VR-CAP, w którym winkrystynę zastąpiono bortezomibem (abstr. 8500). Schemat VR-CAP w porównaniu z klasycznym R-CHOP znamiennie wydłużył medianę czasu wolnego od progresji (24,7 mies. w porównaniu z 14,4 mies.; HR 0,63 [0,500,79]; p < 0,001) kosztem nieznacznie gorszej tolerancji (częściej małopłytkowość, konieczność przetoczeń preparatów płytkowych, neuropatia obwodowa). Po 4 latach 
obserwacji w grupie chorych leczonych VR-CAP nie osiągnięto mediany czasu całkowitego przeżycia, ale 4-letnie przeżycia są w tej grupie wyższe o 10\%.

Selineksor (KPT-330) to nowy lek związany z transportem jądrowym. Jest to doustny inhibitor XPO1 — enzymu odpowiedzialnego za usuwanie z jądra komórki nowotworowej białek supresji nowotworów. Zastosowanie selineksoru powoduje akumulację białek supresorowych w jądrze i silne działanie przeciwnowotworowe. W badaniu I fazy w grupie uprzednio intensywnie leczonych chorych na różne typy chłoniaków lek okazał się bardzo dobrze tolerowany i może być stosowany przewlekle bez wysokiego ryzyka zdarzeń niepożądanych.

\section{Nowotwory głowy i szyi}

Monika Rucińska

Wiele badań koncentruje się na poszukiwaniu czynników prognostycznych i predykcyjnych poprzez retrospektywną analizę materiału tkankowego z wcześniejszych badań. W planowanych uprzednio badaniach nie oceniano bowiem prospektywnie znaczenia zakażenia HPV czy też jego surogatu — zwiększonej ekspresji białka P16. Przykładem jest analiza przeprowadzona w materiale tkankowym chorych leczonych w badaniu II fazy oceniającym wartość cetuksymabu dołączonego do radioterapii w porównaniu z wyłączną radioterapią u chorych na miejscowo zaawansowanego raka gardła lub krtani. Zgodnie z wcześniejszym doniesieniem, niezależnie od stanu P16, dodanie cetuksymabu do radioterapii poprawia kontrolę miejscową, przeżycia całkowite i wolne od choroby. Obecnie okazało się, że stan P16 jest silnym czynnikiem prognostycznym. Niezależnie od tego chorzy na raka ustnej części gardła z ekspresją tego białka odnieśli większą korzyść z zastosowania cetuksymabu w zakresie kontroli miejscowej oraz czasu całkowitego przeżycia, aczkolwiek brak jeszcze ostatecznych dowodów pozwalających na uznanie stanu P16 za czynnik predykcyjny dla leczenia cetuksymabem (abstr. 6001).

Trwa dyskusja nad rolą indukcyjnej chemioterapii w zaawansowanych nowotworach obszaru głowy i szyi. Nadal brak jednoznacznych wniosków, co wynika między innymi z niejednorodnej konstrukcji badań w tym zakresie. Mimo wysokiego odsetka odpowiedzi i zmniejszenia ryzyka odległych przerzutów wpływ indukcyjnej chemioterapii na całkowite przeżycie nie jest ustalony. Podjęto natomiast próbę oceny wartości indukcyjnej chemioterapii jako czynnika pozwalającego na zmniejszenie dawki radioterapii, co mogłoby w przyszłości ograniczyć późny odczyn popromienny (abstr. 6006). Badanie II fazy przeprowadzono w grupie chorych na raka ustnej części gardła ze współistniejącym zakażeniem HPV. Wiadomo, że chorzy na raka na podłożu zakażenia HPV żyją dłużej, zatem w tej grupie późny odczyn popromienny stanowi istotny problem. Po 2 latach obserwacji wykazano, że u chorych z całkowitą odpowiedzią kliniczną po indukcyjnej chemioterapii radioterapia zmniejszoną dawką (54 Gy/27 fr) pozwoliła na uzyskanie wysokich odsetków 2-letnich przeżyć (PFS 84\% i OS 95\%). Analiza podgrup wykazała, że szczególnie dobre wyniki osiągnięto u chorych palących mniej oraz z mniej zaawansowaną chorobą (< T4 i < N2c). Indukcyjna chemioterapia nie przyniosła także korzyści chorym na zaawansowanego raka nosowej części gardła otrzymującym równoczesną radiochemioterapię (abstr. 6003). Chorych przydzielono losowo do wyłącznej radiochemioterapii lub poprzedzonej 3 cyklami indukcyjnego leczenia (gemcytabina, cisplatyna, paklitaksel). Nie wykazano różnic w medianach przeżyć całkowitych, wolnych od choroby ani wolnych od przerzutów odległych, natomiast indukcyjna chemioterapia zwiększała liczbę powikłań.

Działania profilaktyczne w zakresie nowotworów obszaru głowy i szyi od lat koncentrują się w zasadzie na ograniczeniu palenia tytoniu, natomiast w tym roku zaprezentowano badanie oceniające rolę erlotynibu w zapobieganiu zachorowaniom na raka jamy ustnej u osób ze zmianami przednowotworowymi (abstr. 6007). Chorych z takimi zmianami, u których dodatkowo stwierdzono niestabilność satelitarną pod postacią utraty heterozygotyczności (co stanowi niekorzystny czynnik rokowniczy), przydzielano losowo do rocznego leczenia erlotynibem lub placebo i prowadzono 3-letnią obserwację w kierunku zachorowania na raka jamy ustnej. Nie wykazano wpływu erlotinibu na czas do wystąpienia raka.

\section{Rak płuca}

Rafał Dziadziuszko

Mija 10 lat od odkrycia roli mutacji genu EGFR w niedrobnokomórkowym raku płuca, co zmieniło podejście do leczenia tej choroby. Dzięki postępowi w badaniach molekularnych NDRP staje się chorobą coraz bardziej zróżnicowaną, a poszczególne podtypy tego częstego nowotworu paradoksalnie zaczynają spełniać kryteria choroby rzadkiej. Wiemy, że raki z różnymi mutacjami mają odmienny przebieg i powinny być leczone w sposób ukierunkowany. Te zagadnienia są obecnie najważniejszym kierunkiem badań. Jak dotąd nie udało się jednak potwierdzić korzyści z leków molekularnych w leczeniu uzupełniającym. Podczas tegorocznego kongresu zaprezentowano wyniki badania RADIANT, oceniającego erlotynib w porównaniu z placebo w uzupełniającym leczeniu chorych na NDRP w stopniu IB-IIIA, po przebytym radykalnym zabiegu operacyjnym i ewentualnie uzupełniającej chemioterapii. Badanie zaplanowano 8 lat temu, zatem zgodnie z ówczesną wiedzą kryterium włączenia był dodatni wynik testu FISH (wysoka 
liczba kopii genu EGFR) lub dodatnia reakcja barwna na obecność białka EGFR.W tak dobranej grupie nie stwierdzono różnic w zakresie czasu przeżycia wolnego od choroby, co było pierwszorzędowym punktem końcowym badania (abstr. 7501). Zgodnie z obecną wiedzą przeprowadzono dodatkowo analizę mutacji genu EGFR, wykazując u chorych z mutacją aktywującą genu EGFR (delecja egzonu 19. lub mutacja L858R) w guzie wydłużenie pod wpływem erlotynibu mediany czasu wolnego od choroby (z 28,5 mies. do 46,4 mies.), jednak różnica, mimo że znacząca numerycznie, nie była znamienna. Nie wykazano także różnic w zakresie całkowitego czasu przeżycia ( $p=0,815)$.

Wyniki prezentowanych w ub. roku badań LUX-Lung 3 i LUX-Lung 6, wykazały znamienne wydłużenie mediany czasu wolnego od progresji pod wpływem afatynibu w leczeniu 1. linii chorych na zaawansowanego NDRP z mutacjami EGFR w porównaniu z chemioterapią (cisplatyna i pemetreksed w badaniu LUX-Lung 3 oraz cisplatyna i gemcytabina w badaniu LUX-Lung 6). Połączona analiza danych z obu badań przedstawiona podczas tegorocznego kongresu wykazała znamienne wydłużenie mediany czasu przeżycia całkowitego przy zastosowaniu afatynibu. Korzyść ta dotyczyła jednak jedynie chorych z delecją w egzonie 19. genu EGFR, nie zaobserwowano natomiast żadnej korzyści w grupie chorych z mutacją punktową L858R w egzonie 21 (abstr. 8004). To pierwsze badanie potwierdzające korzyść w zakresie czasu przeżycia całkowitego z leczenia anty-EGFR zastosowanego w 1. linii leczenia u chorych na NDRP.

Pojawiają się inhibitory kinaz tyrozynowych 3. generacji. CO-1686 (abstr. 8010) czy AZD9291 (abstr. 8009) to leki swoiste dla zmutowanej formy białka EGFR. W badaniach I fazy w grupie chorych na zaawansowanego raka gruczołowego płuca z mutacją aktywującą EGFR i nabytą opornością (mutacja T790M) na stosowany uprzednio inhibitor kinazy tyrozynowej wykazały obiecujący odsetek obiektywnych odpowiedzi. Oddziaływanie z wyłącznie nieprawidłowym białkiem pozwala uniknąć typowej toksyczności - biegunek i wysypek. Leki te wykazują również aktywność u chorych z przerzutami do ośrodkowego układu nerwowego. Necitumumab to nowe przeciwciało blokujące zewnątrzbłonową domenę receptora EGFR, które dołączone go chemioterapii (cisplatyna i gemcytabina) poprawia medianę czasu przeżycia wolnego od progresji (HR $0,84, p=0,012$ ) oraz czasu całkowitego przeżycia (HR 0,85, $\mathrm{p}=0,20)$ w porównaniu z wyłączną chemioterapią u chorych na uogólnionego raka płaskonabłonkowego płuca, choć korzyść numerycznie wynosi 6 tygodni (abstr. 8008). Ramucirumab, ludzkie przeciwciało monoklonalne klasy lgG1, wiąże się z domeną zewnątrzkomórkową receptora dla naczyniowo-śródbłonkowego czynnika wzrostu, dołączony do docetakselu w 2. linii leczenia chorych na NDRP wpływa znamiennie na poprawę mediany czasu wolnego od progresji (4,5 mies. w porównaniu z 3 mies. w grupie leczonej wyłącznie docetakselem) oraz czasu całkowitego przeżycia (10,5 mies. w porównaniu z 9,0 mies.), choć numeryczne różnice są bardzo niewielkie.

Chorzy z rearanżacją genu ALK odnoszą niewątpliwą korzyść z leczenia celowanego. Kryzotynib zastosowany w 1. linii leczenia u chorych na zaawansowanego NDRP w porównaniu z chemioterapią (pochodne platyny i pemetreksed) poprawił odsetek obiektywnych odpowiedzi (z 45\% do 74\%) oraz wydłużył znamiennie medianę czasu przeżycia wolnego od progresji (z 7 mies. do 10,9 mies., HR 0,46, p < 0,0001; abstr. 8002). W przypadku oporności na kryzotynib pojawia się możliwość zastosowania cerytynibu (abstr. 8003). Kryzotynib jest natomiast również badany u chorych z amplifikacją genu dla receptora cMET, która jest nowym celem molekularnym u chorych z rakiem gruczołowym płuca (abstr. 8001).

\section{Nowotwory OUN}

Monika Rucińska

Chemioterapia PCV zastosowana w uzupełnieniu pooperacyjnej standardowej radioterapii u chorych na glejaki o niskiej złośliwości poprawia wyniki leczenia. Przedstawiono wyniki wieloletniej obserwacji chorych na glejaki G2 (oligoastrocytoma, oligodendroglioma) po nieradykalnej operacji (abstr. 2000). U chorych otrzymujących uzupełniającą chemioterapię uzyskano dłuższą medianę czasu wolnego od progresji (10,4 roku w porównaniu z 4,0 latami przy zastosowaniu wyłącznej radioterapii) oraz wyższe odsetki przeżyć 5-i 10-letnich (odpowiednio $73 \%$ w porównaniu z $64 \%$ oraz $62 \%$ w porównaniu z 41\%). Mimo że skojarzone leczenie powodowało większy odsetek objawów niepożądanych ze strony szpiku i przewodu pokarmowego, to jednak duża korzyść w przeżyciach pozwala uznać pooperacyjną radiochemioterapię za nowy standard leczenia glejaków o niskiej złośliwości po nieradykalnym zabiegu. Glejaki o niskiej złośliwości charakteryzują się powolnym wzrostem, niejednokrotnie długoletnim bezobjawowym przebiegiem i dotyczą populacji młodych ludzi. Warto więc pamiętać, że nie zawsze bezzwłoczna radioterapia jest niezbędna już w chwili rozpoznania i czasami może być odroczona. Z uwagi na przewidywany długi czas życia chorych niezmiernie ważna jest prawidłowo przeprowadzona radioterapia, im bardziej precyzyjna (zastosowanie planowania, jak przy radioterapii stereotaktycznej, mikrokolimatorów), tym mniejsze zaburzenia neuropoznawcze w późniejszych latach (abstr. 2035).

Glejak o wysokiej złośliwości to najczęstszy guz mózgu u dorosłych, charakteryzujący się wyjątkowo złym rokowaniem. Standardowym leczeniem pozostaje skojarzenie radioterapii z temozolomidem, jednak wyniki leczenia są złe. Temozolomid działa jedynie u chorych z hipermetylacją promotora MGMT w guzie. U chorych bez tego zaburzenia 
temozolomid nie przynosi istotnej korzyści. Temsyrolimus dołączony do radioterapii u takich chorych także nie poprawia wyników leczenia (abstr. 2003). Badania molekularne glejaków wielopostaciowych mogą pomóc wyodrębnić podtypy, w których zastosowanie leków ukierunkowanych może przynieść większą korzyść (abstr. 2001, bewacyzumab dodany do standardowego leczenia glejaka podtyp proneural tumor znamiennie poprawia przeżycia całkowite, mediana OS 17,1 mies. w porównaniu z 12,2 mies. dla leczenia standardowego).

\section{Nowotwory przewodu pokarmowego}

Marzena Wełnicka-Jaśkiewicz

Zastosowanie oksaliplatyny w okołooperacyjnym leczeniu raka odbytnicy było w ostatnich latach przedmiotem kilku dużych badań z losowym doborem chorych. W przedoperacyjnej radiochemioterapii nie wykazano dotąd korzyści z dołączenia oksaliplatyny (m.in. ACCORD-12, PETACC-6 czy NSAPB R-04). W tym roku zaprezentowano wyniki dwóch podobnie skonstruowanych badań, oceniających wartość oksaliplatyny w leczeniu przedoperacyjnym (z radioterapią) i pooperacyjnym chorych na miejscowo zaawansowanego (T3/4 lub cN+) raka odbytnicy. W badaniu CAO/ARO/AIO odsetek 3- i 5-letnich przeżyć wolnych od nawrotu był znamiennie wyższy w grupie chorych leczonych oksaliplatyną, co jednak nie przełożyło się na poprawę przeżyć całkowitych (abstr. 3500). W badaniu PETACC-6 nie wykazano korzyści w medianach DFS i OS (abstr. 3501), a zatem oksaliplatyna w przedoperacyjnej radiochemioterapii nie powinna być zalecana. Natomiast zastosowanie oksaliplatyny wyłącznie w leczeniu uzupełniającym znamiennie zwiększyło odsetki 3-letnich przeżyć wolnych od choroby, ale tylko u chorych w III stopniu klinicznego zaawansowania (abstr. 3502, badanie ADORE). Wobec negatywnych wyników wcześniejszych badań nadal nie jest to zalecane postępowanie.

W leczeniu raka jelita grubego w stadium uogólnienia standardem jest chemioterapia, ewentualnie kojarzona z lekami molekularnie ukierunkowanymi. W odniesieniu do 1. linii leczenia celowość dołączenia przeciwciał do chemioterapii jest jednak przedmiotem dyskusji. Zaprezentowane w tym roku badania nie rozwiały tych wątpliwości, aczkolwiek mediana całkowitego czasu przeżycia przekroczyła już 30 mies. i to powinno być punktem odniesienia do dalszych badań (abstr. LBA 3). Być może lepszy dobór chorych oparty na molekularnych czynnikach predykcyjnych wpłynie na poprawę efektów leczenia. Przykładem są retrospektywne analizy materiału tkankowego od chorych uczestniczących w badaniach OPUS i CRYSTAL (skojarzone leczenie I linii - chemioterapia FOLFOX lub FOLFIRI i cetuksymab), polegające na oznaczeniu dodatkowych mutacji w rodzinie genów RAS (KRAS także poza kodonem 12. i 13. oraz NRAS; abstr. 3505 i 3506). Potwierdzono, że chorzy z mutacjami RAS nie odnoszą korzyści z dołączenia cetuksymabu, jednocześnie chorzy bez jakichkolwiek mutacji RAS uzyskują lepszy wynik leczenia w porównaniu z grupą z mutacjami KRAS wyłącznie w kodonie 12. i 13. Taki rozszerzony panel oznaCzeń mutacji RAS jest obecnie standardem przy kwalifikacji chorych na uogólnionego raka jelita grubego do leczenia przeciwciałami przeciwko receptorowi dla naskórkowego czynnika wzrostu.

Leczenie podtrzymujące po 1. linii w raku jelita grubego jest nieustannie przedmiotem badań. Zastosowanie bewacyzumabu z kapecytabiną pozwala na znamienne wydłużenie czasu do progresji, szczególnie u chorych z metachronicznymi przerzutami i usuniętym guzem pierwotnym oraz dobrą odpowiedzią na leczenie 1. linii, jednak nie wpływa na całkowite przeżycie (badanie CAIRO, abstr. 3504). Podtrzymujące leczenie 5-fluorouracylem i bewacyzumabem wydłuża czas do progresji, ale również pozostaje bez wpływu na całkowite przeżycie (abstr. 3503). Nie należy zapominać, że leczenie podtrzymujące jest długotrwałe, toksyczne i kosztowne, i stanowi znaczne obciążenie dla chorego i dla systemu opieki zdrowotnej. Obecnie nie jest ono zalecane. Warto natomiast rozważyć usunięcie guza pierwotnego (także bezobjawowego) u chorych w stadium uogólnienia, szczególnie pozostających w dobrym stanie sprawności (abstr. 3527). Kanadyjskie badanie populacyjne wykazało, że pozwala to uzyskać wydłużenie mediany całkowitego czasu przeżycia z 8,4 mies. do 19,7 mies., niezależnie od udziału chemioterapii, wieku i chorób towarzyszących.

Wielu nowotworom towarzyszą cechy stanu zapalnego (gorączka, wzrost poziomu CRP), które często są wskaźnikiem gorszego rokowania. Na poziomie molekularnym wiąże się to $z$ aktywacją szlaku sygnałowego Jak/STAT. Ruksolitynib, inhibitor ligandów dla tego szlaku — kinazy Jak1 i Jak2 - dodany do kapecytabiny u chorych na opornego na chemioterapię raka trzustki pozwala na poprawę wyników leczenia (znamienne poprawia odsetki 3-, 6- i 12-miesiecznych całkowitych przeżyć oraz kontrolę objawów, ale tylko u chorych z wartością CRP > 13 mg/l, abstr. 4000).

\section{Nowotwory ginekologiczne}

Radosław Mądry

W leczeniu raka jajnika nadal najważniejszą rolę odgrywa chirurgia i jej doszczętność (a więc maksymalna cytoredukcja) podczas pierwszego zabiegu operacyjnego. W celu poprawy wyników leczenia, szczególnie w zaawansowanym stadium nowotworu, od wielu lat prowadzone są badania dotyczące wartości neoadiuwantowej chemioterapii (NAC). W Stanach Zjednoczonych w ostatnich latach obserwuje się stały wzrost odsetka chorych otrzymujących NAC, mimo że nie poprawia to wyników leczenia (abstr. 5586, bada- 
nie populacyjne). Na podstawie badań CHORUS i EORTC prezentowanych w ostatnich latach wydaje się, że obecnie NAC powinna być stosowana jedynie u chorych z przeciwwskazaniami do rozległego zabiegu operacyjnego. Trwa natomiast badanie japońskie, w którym zastosowano bardziej agresywną NAC (8 cykli karboplatyny i paklitakselu). Chore otrzymujące NAC w porównaniu z chorymi poddanymi pierwotnie zabiegowi cetoredukcyjnemu częściej mogły być poddane resekcji okołoaortalnych węzłów chłonnych, rzadziej istniała u nich konieczność resekcji jelita grubego i występowało mniej powikłań pooperacyjnych 3. i 4. stopnia (abstr. 5508). Leczenie operacyjne po NAC powinno się odbywać drogą laparotomii, a laparoskopia zdecydowanie nie jest zalecana, także w grupie chorych, które uzyskały całkowitą remisję. W małej grupie wykazano, że pomimo całkowitej resekcji u chorych operowanych laparoskopowo znamiennie wcześniej rozpoczynano leczenie systemowe 2. linii (abstr. 5589; 8,3 mies. w porównaniu z 15,3 mies. u chorych poddanych laparotomii; $\mathrm{p}=0,02$ ).

Bewacyzumab w leczeniu raka jajnika poprawia przeżycie, nadal jednak brak markerów predykcyjnych. Przeprowadzono retrospektywną analizę materiału tkankowego chorych leczonych w badaniu ICON7 (kohorta chorych z Niemiec, abstr. 5509). Wykorzystując sygnatury molekularne zdefiniowane w projekcie TCGA (The Cancer Genome Atlas), wyodrębniono 4 podtypy molekularne (zróżnicowany - 20\%, immunoreaktywny - 33\%, mezenchymalny - 19\% i proliferujący - 25\%). Chore z podtypem mezenchymalnym i proliferującym uzyskały największą korzyść z zastosowania bewacyzumabu (wydłużenie mediany czasu wolnego od progresji o odpowiednio 8,2 mies. i 10,1 mies.). Autorzy badania uważają, że korzyść z bewacyzumabu może być zależna od podtypu, a molekularna klasyfikacja pomoże spersonalizować leczenie, aczkolwiek te dane wymagają walidacji. Zastosowanie innego testu - 63-genowej sygnatury AADx-Alamc - pozwala na wyodrębnienie 2 podtypów: „proangiogenny", gorzej rokujący, w którym występuje wzmożenie angiogenezy, i „immunomolekularny", lepiej rokujący, w którym występuje stłumienie angiogenezy. Zgodnie z retrospektywną analizą materiału tkankowego chorych na surowiczego raka jajnika leczonych w badaniu ICON7 (kohorta chorych z Wielkiej Brytanii) zastosowanie bewacyzumabu w podtypie immunomolekularnym skraca medianę czasu do progresji (z 35,8 mies. do 18,5 mies.) oraz całkowitego czasu przeżycia w porównaniu z grupą otrzymującą wyłącznie chemioterapię (abstr. 5502). W podtypie proangiogennym bewacyzumab wpłynął na wydłużenie mediany czasu do progresji (z 12,3 mies. do 17,4 mies.).

Wyniki chemioterapii 2. linii w raku jajnika są nadal złe, stąd budzą zainteresowanie badania zzastosowaniem leków molekularnych. Skojarzenie olaparibu z cedyranibem poprawia wyniki w porównaniu z wyłącznymi olaparibem (media- na czasu do progresji odpowiednio 17,7 mies. i 9,0 mies., $\mathrm{p}=0,005$ ), szczególnie u chorych bez mutacji BRCA (abstr. LBA 5500). Leczenie skojarzone było jednak obarczone większą toksycznością i nie przedstawiono analizy jakości życia. Konieczne jest zatem przeprowadzenie prospektywnego badania porównującego to postępowanie z chemioterapią 2. linii.

\section{Czerniaki}

Piotr Rutkowski

Rosnąca zachorowalność na czerniaki skóry (podwojenie liczby zachorowań w ciągu ostatniej dekady) i agresywny przebieg choroby u znacznej części chorych stanowi istotne wyzwanie dla współczesnej onkologii. W ostatnich latach obserwuje się znaczny postęp w zakresie leczenia systemowego. Główne kierunki badań to immunoterapia (głównie nieswoista) oraz hamowanie szlaku BRAF i MEK.

W uzupełniającym leczeniu czerniaków o wysokim ryzyku nawrotu jak dotąd jest zarejestrowany tylko jeden lek - interferon. Ipilimumab zastosowany uzupełniająco u chorych na czerniaka w III stopniu po całkowitej resekcji w porównaniu z placebo poprawia przeżycia wolne od nawrotu (abstr. LBA9008 wyniki analizy etapowej badania EORTC). Niestety, toksyczność tego leczenia podważa możliwość takiego zastosowania ipilimumabu jako standardu; w badaniu stwierdzono 1,3\% zgonów związanych z toksycznością leczenia, a 52\% chorych przerwało leczenie uzupełniające ipilimumabem z powodu toksyczności. Trwają także badania leków ukierunkowanych na receptor PD-1 (abstr. 9000 - pembrolizumab, 9002 - niwolumab).W większości są to badania wczesne i konieczna jest weryfikacja tych obiecujących wyników w badaniach III fazy. Wiadomo, że terapia anty PD-1 pozwala na uzyskanie długotrwałej odpowiedzi, aczkolwiek chorzy uprzednio leczeni ipilimumabem uzyskują mniejszą korzyść. Leki anty PD1 mają względnie niską toksyczność, a ekspresja liganda dla receptora PD1 (PD-L-1) jest obecnie badana pod kątem wartości predykcyjnej. Nie wiadomo natomiast, jak długo powinno trwać leczenie anty-PD1, w jaki sposób można je kojarzyć z ipilimumabem (sekwencyjnie czy jednoczasowo) i czy obserwowana korzyść kliniczna przeważa nad toksycznością.

Leczenie molekularnie ukierunkowane czerniaków to obecnie leki zarejestrowane w świecie - wemurafenib, dabrafenib (inhibitory kinazy BRAF) oraz trametynib (inhibitor kinazy MEK), zarejestrowany wyłącznie w Stanach Zjednoczonych. Główne kierunki badań to obecnie kojarzenie tych leków, co pozawala na uzyskanie wysokich odsetków odpowiedzi i wydaje się obecnie najbardziej wartościową formą leczenia u chorych na czerniaka z mutacją BRAF z szybką dynamiką i dużą masą guza (abstr. 9009, 9010, 9011). 


\section{Mięsaki}

Piotr Rutkowski

Przedstawiono odległe wyniki badania III fazy S0033, oceniającego wartość imatynibu w leczeniu chorych na zaawansowane postaci GIST (abstr. 10508). Wykazano, że $26 \%$ chorych żyło co najmniej 8 lat, a odsetek 10-letnich przeżyć wyniósł $22 \%$. Chorzy na GIST z obecnością mutacji w egzonie 9 KIT mieli istotnie krótsze przeżycie.

\section{Leczenie wspomagające}

Renata Zaucha

Przerzuty nowotworowe do kości występują u ok. 80\% chorych, a towarzyszące im objawy kliniczne (m.in. ból, patologiczne złamania, hiperkalcemia, zespół ucisku rdzenia) istotnie pogarszają jakość życia chorych. Leczenie przerzutów do kości obejmuje zwykle kojarzenie miejscowej radioterapii lub chirurgii z leczeniem systemowym i stosowaniem promieniotwórczych izotopów strontu, samaru czy radu. Zalecenia amerykańskich i europejskich towarzystw zgodnie proponują stosowanie kwasu zoledronowego i denozumabu w profilaktyce zdarzeń kostnych. Obecnie kwas zoledronowy (zarejestrowany we wszystkich typach nowotworów) podawany jest w postaci dożylnych wlewów co 4 tygodnie, jest on jednak równie skuteczny w podawaniu co 12 tygodni (abstr. 9500, badanie OPTIMIZE-2). Podawanie co 12 tygodni jest wygodniejsze dla chorych, tańsze i prawdopodobnie mniej toksyczne. Potwierdzono również, że denozumab w porównaniu z kwasem zoledronowym skuteczniej zapobiega przerzutom do kości, niezależnie od lokalizacji i liczby przerzutów (abstr. 9501, analiza zbiorcza podgrup chorych z wcześniejszych trzech badań prospektywnych III fazy z denozumabem).

Połączenie aprepitantu z setronami i deksametazonem jest zalecane w profilaktyce nudności i wymiotów u chorych otrzymujących wysokoemetogenną chemioterapię. Aprepitant w tym postępowaniu stosowany jest przez 3 kolejne dni. Badacze $z$ Włoch podjęli próbę oceny skuteczności aprepitantu z deksametazonem w porównaniu z metoklopramidem $z$ deksametazonem stosowanymi w dniach 2.i 3. (abstr. 9503). W pierwszym dniu wszyscy chorzy otrzymywali aprepitant (125 mg), palonosetron $(0,25 \mathrm{mg})$ i deksametazon (8 mg), a w 2. i 3. dniu otrzymywali w sposób losowy metoklopramid (20 mg) i deksametazon (8 mg) lub aprepitant $(80 \mathrm{mg})$ i deksametazon $(8 \mathrm{mg})$. Kontrola nudności wymiotów, zarówno wczesnych, jak i opóźnionych była w obu grupach podobna. Autorzy sugerują, że w 2. I 3. dniu leczenia aprepitant można zastąpić tańszym i łatwiej dostępnym metoklopramidem. NEPA jest nowym lekiem przeciwwymiotnym, który zawiera dwa inhibitory — dla NK1R (netupitant, długotrwale wiąże się receptorem po podaniu pojedynczej dawki) i dla 5-HT3 (palonosteron). W podwójnie zaślepionym badaniu z losowym doborem chorych wykazano, że pojedyncza dawka NEPA skuteczniej niż palonosetron zapobiega nudnościom i wymiotom podczas chemioterapii z udziałem antracyklin (abstr. 9502).

Większość chorych po zakończeniu leczenia onkologicznego ogranicza aktywność i nie uprawia żadnych regularnych ćwiczeń fizycznych. Badacze z Australii wykazali, że nadzorowany program ćwiczeń usprawniających (trzymiesięczny trening aerobowy i oporowy) po zakończeniu leczenia przeciwnowotworowego z powodu różnych nowotworów poprawia jakość życia ozdrowieńców (abstr. 9533). Wykazano znamienną poprawę w zakresie wartości ciśnienia tętniczego krwi, masy ciała, zmęczenia, sprawności fizycznej, psychicznej oraz jakości życia. W dodatkowej analizie stwierdzono, że u osób stosujących ćwiczenia wydatki medyczne były o 12 do 14\% niższe w porównaniu z grupą kontrolną.

\section{Nowotwory układu moczowego}

Piotr Potemski

Wykład zdominowały doniesienia dotyczące raka gruczołu krokowego. Najbardziej dyskutowanym doniesieniem tegorocznego kongresu w zakresie nowotworów układu moczowego było zaprezentowane w sesji plenarnej badanie oceniające korzyść z dołączenia docetakselu do hormonoterapii u chorych na uogólnionego, wrażliwego na kastrację raka gruczołu krokowego (abstr. LBA2). W badaniu wykazano znamienne wydłużenie mediany całkowitego czasu przeżycia (z 44 do 58 mies.) oraz zmniejszenie względnego ryzyka zgonu o 39\% ( $p<0,001)$ w grupie leczonej w sposób skojarzony. Szczególnie wyraźnie było to widoczne u chorych z przerzutami do narządów miąższowych lub z więcej niż 4 przerzutami w układzie kostnym, także pod kręgosłupem i miednicą. Wyniki tego badania, mimo że dość jednoznaczne, są sprzeczne z wynikami opublikowanego w 2013 roku badania GETUG-15, przeprowadzonego w takiej samej populacji chorych. Być może wynika to z krótkiego okresu obserwacji tegorocznego badania (mała liczba zdarzeń powoduje, że mediany są szacowane, a nie rzeczywiste), niemniej jednak nakazuje ostrożność w interpretacji. Ewentualna zmiana standardu wymaga na pewno dłuższej obserwacji chorych w tym badaniu.

W leczeniu zaawansowanego raka gruczołu krokowego pojawiły się nowe leki hormonalne, jednak nie są one aktywne u wszystkich chorych. Poszukuje się predykcyjnych czynników molekularnych, które pomogą lepiej określić wrażliwość na nowe leki. AR-V7 to wariant receptora androgenowego, w którym jest on pozbawiony domeny wiążącej ligand. Jego obecność możemy oznaczyć w krążących we krwi komórkach nowotworowych. U chorych leczonych abirateronem i enzalutamidem, u których stwierdzono 
obecność AR-V7, mediana czasu wolnego od progresji oraz odsetek odpowiedzi biochemicznej były znamiennie gorsze, co sugeruje, ze AR-V7 może mieć związek z pierwotną i wtórną opornością na enzalutamid i abirateron (abstr. 5001). Konieczna jest jednak prospektywna walidacja wartości predykcyjnej i prognostycznej AR-V7.

Badanie obserwacyjne wskazuje, że u chorych po radykalnym leczeniu miejscowym, ze wznową wyłącznie biochemiczną, można odroczyć hormonoterapię do czasu progresji. Takie postępowanie w porównaniu z niezwłocznie rozpoczętą hormonoterapią pozwala uzyskać podobne mediany czasu całkowitego przeżycia i czasu przeżycia swoistego dla raka gruczołu krokowego (abstr. 5003). Badanie III fazy dotyczące tego zagadnienia jest w toku.

W ostatniej dekadzie wprowadzono do leczenia zaawansowanego raka nerki kilka leków molekularnych. Badania tych leków były jednak przeprowadzone głównie w grupach chorych na raka jasnokomórkowego. W efekcie nie opracowano standardu leczenia systemowego zaawansowanych postaci raka nerki o typie innym niż jasnokomórkowy. W badaniu Il fazy z losowym doborem chorych porównano ewerolimus i sunitynib w 1 . linii leczenia (abstr. 4505). Oba leki wykazały umiarkowaną skuteczność (mediana PFS dla sunitynibu wyniosła 6,1 mies., a dla ewerolimusu 4,1 mies., $p=0,6)$, a badanie przerwano po analizie okresowej. Analiza podgrup z badania III fazy z temsyrolimusem z 2007 sugerowała jego skuteczność u chorych na raka nerki innego niż jasnokomórkowy, obecnie jednak lek ten nie jest w Polsce refundowany.

\section{Rak piersi}

Aleksandra Łacko

W leczeniu HER2-dodatniego raka piersi w ciągu ostatniej dekady dokonał się znaczący postęp. Blokowanie receptora HER2 poprzez zastosowanie trastuzumabu jest jednak u części chorych nieskuteczne, stąd próby intensyfikacji leczenia poprzez dołączenie inhibitora kinazy — lapatynibu, zahamowanie dimeryzacji skojarzeniem trastuzumabu z pertuzumabem, dołączenie do trastuzumabu leku cytotoksycznego - TDM1, czy wreszcie intensywnie badane ostatnio hamowanie szlaku PI3K czy mTOR. Zastosowanie podwójnej blokady anty-HER2 (trastuzumab skojarzony z lapatynibem) pozwala uzyskać lepsze wyniki w leczeniu indukcyjnym oraz paliatywnym, choć obarczone jest większą toksycznością. Leczenie to nie przynosi jednak korzyści chorym na wczesnego raka piersi, na co wskazują jednoznacznie wyniki badania ALTTO (abstr. LBA4). Nadal standardem leczenia w tej grupie chorych pozostaje trastuzumab (badanie APHINITY, oceniające korzyść z dołączenia pertuzumabu w leczeniu uzupełniającym, jest w toku). Trastuzumab poprawia także wyniki w uzupełniającym leczeniu chorych z guzami mniejszymi niż $2 \mathrm{~cm}$, niezależnie od stanu pachowych węzłów chłonnych, co potwierdzono w metaanalizie badań III fazy (abstr. 508). Wyniki tej metaanalizy nie odpowiadają jednak na pytanie o wartość trastuzumabu u chorych z guzami mniejszymi niż $1 \mathrm{~cm}$ i bez przerzutów do pachowych węzłów chłonnych.

Analiza materiału z dwóch badań z randomizacją oceniających wartość trastuzumabu w leczeniu uzupełniającym (NCCTG 9831 oraz NSABP B-31) wskazuje, że układ immunologiczny odgrywa krytyczną rolę w odpowiedzi na trastuzumab (abstr. 509). Potwierdzenie tych wyników w kolejnych analizach może zmienić praktykę kliniczną u chorych na HER2-dodatniego raka piersi w zakresie kwalifikacji i sposobu leczenia anty-HER2.

Standardem uzupełniającej hormonoterapii u chorych przed menopauzą jest tamoksyfen, ewentualnie skojarzony z supresją funkcji jajników. Jak dotąd brak było w takim wskazaniu dowodów na korzyść z zastosowania inhibitorów aromatazy.W dwóch dużych badaniach z losowym doborem chorych — SOFT i TEXT — porównano skojarzenie egzemestanu z supresją funkcji jajników wobec tamoksyfenu połączonego z supresją hormonalną. Po ponad 5-letniej obserwacji stwierdzono, że leczenie inhibitorem aromatazy w skojarzeniu z supresją nieznacznie (4\% względnej różnicy), aczkolwiek znamiennie wydłuża medianę czasu przeżycia wolnego od choroby (DFS), natomiast pozostaje bez wpływu na medianę czasu całkowitego przeżycia (abstr. LBA1). W metaanalizie grupy badawczej wczesnego raka piersi (EBCTCG) przeanalizowano wpływ otyłości na czas przeżycia chorych poddanych uzupełniającej hormonoterapii (abstr. 503). Na podstawie oceny 70 badań, w których leczono ponad 80000 chorych, stwierdzono, że u chorych przed menopauzą otyłość zwiększa ryzyko nawrotu i zgonu z powodu raka piersi. Zależności takiej nie wykazano z grupie chorych po menopauzie.

W kolejnym już (po BEATRICE i BETH) badaniu wykazano, że bewacyzumab w leczeniu uzupełniającym nie wpływa na czas przeżycia chorych na wczesnego raka piersi (abstr. 500).

\section{Miscellanea}

Barbara Radecka

Tradycyjnie na zakończenie „Spotkania...” - wykład dotyczący innych ciekawych doniesień przedstawionych podczas kongresu ASCO. Nabłonkowe nowotwory grasicy należą do chorób rzadkich (0,1-0,5/100000). W chwili rozpoznania w większości mogą być leczone miejscowo — operacyjnie lub/i napromienianiem. W zaawansowanych postaciach nabłonkowych nowotworów grasicy stosuje się jednak także wielolekową, opartą o pochodne platyny chemioterapię. Brak jednak standardu postępowania w przypadku niepowodzenia takiej chemioterapii. Przedstawiono 
kilka badań II fazy z zastosowaniem leków molekularnych (abstr. 7525 - sunitynib, abstr. 7526, milciklib, nowy inhibitor kinazy zależnej od cykliny, abstr. 7527 — ewerolimus), w których wykazano, że leki te pozwalają na uzyskanie potwierdzonej radiologicznie odpowiedzi i stabilizacji choroby. Należy jednak podkreślić, że optymalny punkt końcowy dla nowych leków nie jest określony, oraz że nieznane są czynniki predykcyjne dla takiego leczenia.

Białka hedgehog $(\mathrm{Hh})$ są niezbędne do prawidłowego rozwoju embrionów (proliferacja, różnicowanie i dojrzewanie); są one nieaktywne w dojrzałych, zróżnicowanych tkankach, natomiast ulegają reaktywacji w karcynogenezie. Zaburzenia szlaku $H h$ występują w wielu nowotworach i zwykle wiążą się ze wzmożoną repopulacją i opornością na radiochemioterapię. Wismodegib, inhibitor szlaku sygnałowego hedgehog, został warunkowo zarejestrowany w 2012 roku do leczenia zaawansowanych postaci podstawnokomórkowego raka skóry na podstawie badania ERIVANCE. Przedstawiono uaktualnione wyniki tego badania, które potwierdziły obserwowaną wcześniej skuteczność leku (abstr. 9013). W nowej analizie uzyskano wydłużenie mediany czasu trwania odpowiedzi na leczenie z 12,9 do 14,8 mies. w grupie chorych $z$ przerzutami oraz $z 7,6$ do 26,2 mies. w przypadku postaci miejscowo zaawansowanych. Odsetek najczęściej występujących objawów niepożądanych leczenia wismodegibem (m.in. skurcze mięśni, osłabienie, ubytek masy ciała, nudności) nie różnił się istotnie w porównaniu z pierwotną analizą. Zaprzestanie stosowania wismodegibu nie grozi szybką progresją; lek zastosowany ponownie po przerwie wykazuje aktywność (abstr. 9081). U pewnej części chorych na podstawnokomórkowego raka skóry nie można zastosować leczenia chirurgicznego z powodu znacznego zaawansowania i/lub niekorzystnej lokalizacji. Toczy się badanie oceniające przydatność leczenia wismodegibem dla zmniejszenia zaawansowania i poprawy warunków operacyjności (abstr. 9104, badanie VISMONEO).

Odległa kardiotoksyczność to narastający problem w populacji chorych leczonych radykalnie. Chore na raka piersi otrzymujące po zabiegu operacyjnym trastuzumab i chemioterapię miały większe ryzyko niewydolności mięśnia sercowego niż otrzymujące wyłącznie chemioterapię (5-letnie ryzyko odpowiednio 5,3\% i 2,6\%; p <0,0001, abstr. 9504). W analizie wieloczynnikowej stosowanie trastuzumabu było niezależnym czynnikiem zwiększającym ryzyko powikłań kardiologicznych, ale tylko w ciągu 1,5 roku od rozpoczęcia leczenia. $U$ chorych leczonych z powodu chłoniaka Hodgkina obserwuje się zwiększone ryzyko powikłań kardiologicznych. Utrzymuje się ono nawet po wielu latach i dotyczy szczególnie osób leczonych w sposób skojarzony (abstr. 9505). W miarę upływu czasu ryzyko powikłań kardiologicznych rośnie, co wymaga obserwacji takich osób nawet wiele lat po przebytym leczeniu. Zaobserwowano także zwiększone ryzyko zgonu z powodu zdarzeń sercowo-naczyniowych w grupie chorych otrzymujących wielolekową chemioterapię z powodu nienasieniaka jądra, szczególnie w pierwszym roku (standaryzowany współczynnik umieralności 5,31, abstr. 9593). Odnotowano szczególnie wysokie ryzyko zgonu z powodu zawału serca i udaru mózgu (standaryzowany współczynnik umieralności odpowiednio 3,45 i 21,72).

Wczesne wyniki badań klinicznych oceniających wartość nowych leków mogą się znacząco różnić od ostatecznych wyników uzyskanych po długotrwałej obserwacji. Autorzy pracy porównali wczesne i odległe wyniki badań klinicznych z randomizacją dotyczących oceny systemowego leczenia raka płuca, piersi i gruczołu krokowego, opublikowanych $w$ renomowanych czasopismach medycznych w latach 1990-2010 (abstr. 6520). Wykazali, że wczesne doniesienia, w porównaniu z publikacjami ostatecznymi, zawierają przeszacowane wyniki w odniesieniu do skuteczności (zwiększenie wartości HR z 0,75 do 0,83; p =0,0003), szczególnie w przypadku radykalnego leczenia $(p<0,001)$, orazzaniżone dane dotyczące objawów niepożądanych (zwiększenie odsetka zdarzeń w stopniu 3. i 4. z 8,5\% do 9,5\%; $p=0,01$ ). Warto także pamiętać, że informacje o hospitalizacjach związanych z leczeniem w ramach badań klinicznych są niedostatecznie raportowane, mimoże konieczność hospitalizacji to poważne zdarzenie niepożądane. Autorzy jednego z doniesień porównali częstość hospitalizacji spowodowanej toksycznością leczenia systemowego chorych na NDRP, raportowaną w badaniach klinicznych i obserwowaną w codziennej praktyce. Na podstawie systematycznego przeglądu piśmiennictwa wykazali, że chorzy leczeni poza badaniami klinicznymi są starsi (mediana wieku 69,2 roku w porównaniu z 62 latami) i znacząco częściej hospitalizowani $(57,5 \%$ w porównaniu z 14,8\%; p < 0,0001) niż chorzy leczeni w badaniach klinicznych. Wskazuje to na konieczność prowadzenia badań populacyjnych i obserwacyjnych.

Ta sesja zakończyła tegoroczne „Spotkanie po ASCO”. Wszystkie wykłady w wersji wirtualnej dostępne są na stronie www.poasco.pl. Kolejne, XIV spotkanie odbędzie się w Gdańsku w dniach 26-27 czerwca 2015 r.

Dr n. med. Barbara Radecka

Opolskie Centrum Onkologii

ul. Katowicka 66a, 45-060 Opole

e-mail:brad@onkologia.opole.pl 